ZOOLOGIA 27 (5): 709-717, October, 2010

doi: $10.1590 /$ S1984-46702010000500007

\title{
Mammal occurrence and roadkill in two adjacent ecoregions (Atlantic Forest and Cerrado) in south-western Brazil
}

\author{
Nilton C. Cáceres'1,6; Wellington Hannibal2; Dirceu R. Freitas33; Edson L. Silva4; \\ Cassiano Roman ${ }^{1} \&$ Janaina Casella ${ }^{5}$
}

\author{
${ }^{1}$ Laboratório de Ecologia e Biogeografia, Departamento de Biologia, CCNE, Universidade Federal de Santa Maria. \\ 97110-970 Santa Maria, RS, Brazil. \\ 2 Departamento de Biociências, Campus II. Rua Oscar Trindade de Barros, Universidade Federal de Mato Grosso do Sul. \\ 79200-000 Aquidauana, MS, Brazil. \\ ${ }^{3}$ Rua Plutão 201, Residencial Sol Nascente. 79950-000 Naviraí, MS, Brazil. \\ ${ }^{4}$ Laboratório de Citogenética, Departamento de Biologia, Instituto de Biociências, Universidade Estadual Paulista. \\ Avenida 24A, 1515, 13506-900 Rio Claro, SP, Brazil. \\ 5 Programa de Pós-Graduação em Ecologia e Conservação, Universidade Federal de Mato Grosso do Sul. Caixa Postal 549, \\ 79070-900, Campo Grande, MS, Brazil. \\ ${ }^{6}$ Corresponding author. E-mail: niltoncaceres@gmail.com
}

\begin{abstract}
This paper examines the frequencies of mammal roadkill in two adjacent biogeographic ecoregions (Atlantic Forest and Cerrado) of Brazil. Mammals were recorded during a seven-year period and over 3,900 km of roads, in order to obtain data for frequencies of species in habitats (sites) and frequencies of species killed by cars on roads. Sites $(n=80)$ within ecoregions (Cerrado, $n=57$; Atlantic Forest, $n=23$ ) were searched for records of mammals. Species surveyed in the entire region totaled 33, belonging to nine orders and 16 families. In the Cerrado, 31 species were recorded in habitats; of these, 25 were found dead on roads. In the Atlantic Forest ecoregions, however, we found 21 species in habitats, 16 of which were also found dead on roads. There was no overall significant difference between ecoregions for frequencies of occurrence in habitats or for roadkills, but there were differences between individual species. Hence, anteaters were mostly recorded in the Cerrado ecoregion, whereas caviomorph rodents tended to be more frequent in the Atlantic Forest ecoregion (seen mainly by roadkills). The greater number of species (overall and threatened) and the greater abundance of species records in the Cerrado suggest that this ecoregion has a greater biodiversity and is better conserved than the Atlantic Forest ecoregion, in the state of Mato Grosso do Sul, south-western Brazil.
\end{abstract}

KEY WORDS. Anteaters; caviomorph rodents; road mortality; highway; transitional vegetation.

Conservation biology is one of the main disciplines that strives to compensate for anthropogenic pressure. The study of ecological landscapes, part of this area of study, provides insights for comparative approaches, such as comparisons between faunal communities of different ecoregions or biomes (e.g. Krasnov \& Shenbrot 1998, López-GonzÁlez 2004).

Ecotonous regions are important biogeographically for two reasons. First, they are generally species-rich (KARK et al. 2006). Second, they sometimes exhibit complex mosaic patterns in geography or vegetation. When more than one biome is present, it is important to assess the extent to which one influences the other(s) (KRASNov \& SHENBrot 1998). Such assessment can be conducted, for example, by investigating the presence of particular species that are characteristic of one biome/ ecoregion in the adjacencies of another. Indeed, the relative abundance of a species will be higher, and its distribution wider, in the biome where the species is known to be more adapted (López-GonzÁlez 2004).Today, one point that deserves consideration when assessing biogeographic patterns is the regional conservation status of a target community, which can lead to misinterpretations of the observed distributional patterns. Discrepancies may exist between the observed distribution and the true (historic) distribution of a species due to disturbance, which may cause changes in the distributional patterns that are not due to community evolution (Lomolino \& Perault 2004). Examples of such disturbances are habitat fragmentation, hunting pressure and roadkill mortality.

Accidents between wildlife and vehicles are one of the main sources of environmental impact, and can result in a reduction in the size of natural populations with consequent bottlenecks and an increased risk of extinction (Forman et al. 2003). Roads are one of the most important factors contribut- 
ing to loss of biodiversity. Their effects range from habitat fragmentation and increased edge effects, to accidents resulting in deaths and consequent population instability (Forman \& Alexander 1998, Santos \& Tabarelli 2002).

Mammal populations worldwide are now fragmented and isolated. Individuals often need to cross wide open matrices between native fragments, becoming exposed to several kinds of risks. Because most mammals are highly mobile, they cross roads often, which makes them more likely to encounter vehicles and be killed by them (Woods \& Munro 1996, Clarke et al. 1998).

Road-related mortality rates increase with road modernization and paving. The latter usually increase vehicular traffic which is directly correlated with accidents between vehicles and wildlife (OrLowsky \& Nowak 2006). In Brazil, few studies have addressed wild fauna road mortality (e.g. CHerem et al. 2007, Melo \& Santos-Filho 2007, Coelho et al. 2008), which is surprising given the country's extensive road system and biodiversity. Most studies on the subject only provide checklists of mammals killed on roads, with no attached information on the causes and/or consequences of mammal mortality. Particularly, no study has focused on the relationships between mammal abundances and roadkills of the adjacent Brazilian Cerrado and Atlantic Forest biomes.

Wide areas in southwestern Brazil have lost their native vegetation, mainly to farming and cattle ranching (Dias 1994). Savanna (here termed Cerrado) and Atlantic Forest vegetations are the main physiognomies in this region. Collectively, in Brazil, only about $35 \%$ of the Cerrado biome (MANTOvani \& Pereira 1998) and 7\% of the original Atlantic Forest (Machado et al. 2004, Нirota 2005) remain.

The aim of this study was to examine the distributional abundances and the mortality rates of non-flying mammals on the roads of a forest-savanna contact region in southwestern Brazil. More precisely, we addressed the relative abundances, rates of mortality on roads, and the threatened state of various species in the two adjacent ecoregions (Atlantic Forest and Cerrado). Our main goal was to compare the two ecoregions with respect to the parameters above, and to analyze their conservation status based mainly on the relative abundances of roadkills.

\section{MATERIAL AND METHODS}

The study region is located in southwestern Brazil, mainly in the state of Mato Grosso do Sul, but also encompassing the extreme southern part of the state of Goiás. Mato Grosso do Sul extends over $358,159 \mathrm{~km}^{2}$, with 78 municipalities and a relatively sparse human population $\left(5.8 \mathrm{indiv} / \mathrm{km}^{2}\right.$ ) (Мато Grosso do Sul 2008). The regions studied in Mato Grosso do Sul and southern Goiás are located within the coordinates $17^{\circ} 40^{\prime}-24^{\circ} 00^{\prime} \mathrm{S}$ and $51^{\circ} 30^{\prime}-56^{\circ} 30^{\prime} \mathrm{W}$ (Fig. 1). The climate is tropical in the north and mostly subtropical in the south.

For the purposes of this report, we separated the region into two ecoregions: a) "Cerrado", in the northeast and west, adjacent to the Pantanal biome and dominated by savannas; and b) "Atlantic" in the southeast, with a preponderance of deciduous forests, and savanna inclusions in several portions (Fig. 1). The main economic activity in the Cerrado is cattle ranching, and in the Atlantic Forest, farming (Mato Grosso do Sul 2008). The Cerrado to the west, near the Pantanal, is generally in a better state of conservation, being a historically less disturbed region where large fragments of the original vegetation still exist. The natural vegetations of the Cerrado in the east and of the Atlantic Forest are for most part highly impacted and are now represented by small isolated fragments (Mantovani \& Pereira 1998, Machado et al. 2004). Currently there is no direct faunal management (fences, faunal bridges or tunnels) of the highways in the study region.

We recorded nonvolant mammals in the study region from 2001 to 2008, in order to obtain data on (a) frequency in each habitat (site); and (b) frequency of deaths due to collision with vehicles, for each species. For the most part, a site was defined as a locality encompassing no more than $1 \mathrm{~km}^{2}$ and situated near roads (usually up to $5 \mathrm{~km}$ from any road). Distances between adjacent sites generally ranged from 10 to 30 $\mathrm{km}$ (minimum distance between sites of $2 \mathrm{~km}$, and maximum of $180 \mathrm{~km}$ ). Here we use the term "frequency" as an estimate of how common, or rare, a given species is in the study region, by considering all sampled sites. Common species were defined as those most frequently recorded within one or both ecoregions, or in most of the study region, using the presence/ absence method. In order to estimate frequencies in habitats, a total of 80 sites were selected (57 in the Cerrado, and 23 in the Atlantic Forest) (Fig. 1). When searching, we conducted direct observations and also recorded species through indirect means such as tracks and carcasses. Our surveys were preferentially conducted along forest trails and edges. For the purposes of our study, we only recorded the presence of the various species at each site, but not their abundances. Therefore, the relative abundance (or rarity) of a species was obtained by combining data from all areas sampled in each ecoregion.

We excluded from our analyses sites that had less than three species of mammals recorded. We adopted this threshold in order to avoid bias, since not all sites had trails or soil characteristics that allowed us to find animals through their footprints, since tracking was the main sampling method used here (see CÁcEREs et al. 2007). Each site was surveyed either once or twice (each time in a different season). Whenever possible, we tried to sample a site twice. In both ecoregions, sites were surveyed during one to four days and were either randomly (24\%) or systematically (76\%) selected in space and time (during the sampling years). The main systematic surveys were as follows: 16 sites in a transitional region (13 in the Atlantic and three in the Cerrado) between the two ecoregions from November 2001 to January 2002; 22 sites around Bodoquena Mountains in the Cerrado from April to June 2002; 11 sites in north-west Mato 


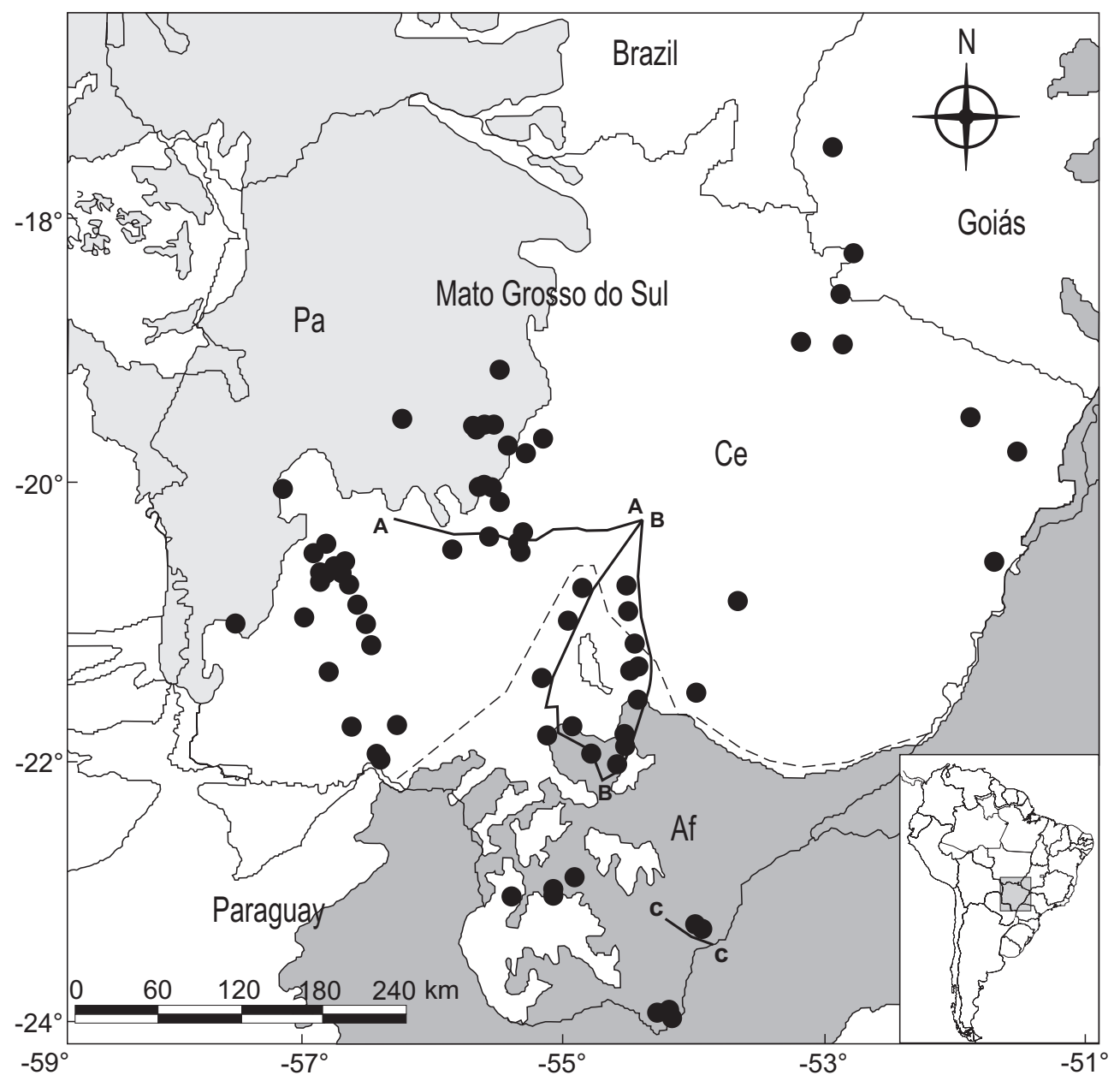

Figure 1. Map showing the 80 localities sampled for mammals in the present study, in south-western Brazil. Biomes: (Af) Atlantic Forest, (Ce) Cerrado, ( $\mathrm{Pa}$ ) Pantanal. Stretch A-A: BR 262 in the Cerrado ecoregion; stretch B-B: BR 163 (at right) and BR 060 and MS 157 and MS 162 (at left) comprising a transitional region of Cerrado-Atlantic Forest; and stretch C-C: BR 487 in the Atlantic ecoregion.

Grosso do Sul in the Cerrado, near the Pantanal boundaries, during August-September 2005 and January-February 2006; and seven sites from the Atlantic ecoregion and five sites from Cerrado in south-eastern Mato Grosso do Sul from July to August 2007.

Small mammal species such as those in Didelphis Linnaeus, 1758 ( $\pm 1 \mathrm{~kg}$ in body mass) were included in the habitat analyses because they are easy to identify in the field based on footprints (Borges \& Tomás 2004). The species of Didelphis most commonly found in the study region is $D$. albiventris Lund, 1840 (CÁceres et al. 2007, 2008). Primates were also included because they are easy to record in transect lines and the different species can be identified through their vocalization patterns (Emmons \& FeER 1997). The remaining mammals included in our analyses were recorded through footprints and/or direct observation in the field (Borges \& Tomás 2004).
We surveyed mammals run over by cars from 2001 to 2008, along the following main highways of Mato Grosso do Sul: BR 262 in the west (crossing the Cerrado), BR 060 and 163 and MS 157 and 162 (termed here as BR 060-163) in the south central region (passing through a transitional region between the Cerrado and the Atlantic Forest), and BR 487 in the southeast (crossing the Atlantic Forest ecoregion) (Fig. 1). We searched for dead mammals by driving along the roads in cars or motorcycles at about $60-70 \mathrm{~km} / \mathrm{h}$, during daylight. A total of 3,900 $\mathrm{km}$ (> 90\%; federal or state highways) of continuous roads (mostly paved) were monitored during the seven years of study (this total was obtained by summing each different stretch surveyed along the entire study area). From this total, 1,200 km were in the Atlantic ecoregion and 2,700 in the Cerrado ecoregion (the latter not only has a larger area in the study region but also a higher proportion of paved roads). Except for 
a $250-\mathrm{km}$ stretch on two selected highways (see below), the remaining road sections (ca. 3,650 km) were sampled randomly during the years in both ecoregions, both in the dry and wet seasons. We searched in roads near the 80 sites where we had previously or concomitantly assessed the frequency of free-ranging mammals.

In order to compare the number of vehicles per ecoregion and how this number influences road mortality, we searched for the mean daily traffic volume (MDV) at the webpage www.dnit.gov.br, which is an official webpage of the Brazilian Government responsible for transportation (Ministério dos Transportes, DNIT/Departamento Nacional de Infraestrutura de Transporte).

Besides random samples along the selected roads (totaling 3,900 km), we chose two (continuous) stretches of road in each ecoregion for systematic monitoring, as follows. On BR 262, we selected a $200 \mathrm{~km}$ (Miranda to Campo Grande) section, and on BR 487, a 50 km (Naviraí to the Rio Paraná bridge) road section. Furthermore, BR 262 (within the Cerrado) was monitored monthly for dead animals for 1.5 years (2003 to 2004; totaling 3,600 km monitored) and BR 487 (within the Atlantic ecoregion) during one year (totaling $600 \mathrm{~km}$ ), in the same period and with the same frequency, in order to balance efforts between the two ecoregions.

At the community level, the frequencies of free-ranging species were tested between ecoregions, as well as for roadkill data, using the non-parametric Wilcoxon test. Because the sampling effort was lower in the Atlantic ecoregion (ca. 40\% less sites for the calculation of the frequencies of free-ranging animals), the relative proportions of records were calculated before running the Wilcoxon test. At the species level, and considering the frequency of free-ranging mammals and the frequency of roadkills (for which about a third of the sampling effort was carried out in the Atlantic ecoregion), the binomial test was used to compare each pair of absolute values (e.g. number of roadkill records for the Cerrado and for the Atlantic ecoregion) for any given species. With the binomial test, it was possible to account for the differences in sampling effort between ecoregions and thus obtain more realistic results. The statistical program used for these analyses was BiosEstat 3.0 (Ayres et al. 2003).

A Non-Metric Multidimensional Scaling Analysis (NMDS) was performed on habitat data, in order to examine the relationships among mammal families when summarized on two axes. The similarity measure to compare ecoregions was the Euclidean distance. The consistency of the diagram was checked by a Shepard diagram and the Stress value (LEGENDRE \& LEGENDRE 1998). The program used for NMDS was PAST version 1.74 (HAMMER et al. 2001). Only species with at least four records were considered in all analyses.

The data for mean daily volume (MDV) of vehicles transiting on the main highway routes monitored for mammals (BR 262 and BR 487) were checked for possible differences. They were tested by the Mann-Whitney non-parametric test, because the data did not meet the criterion of homoscedasticity. Rates of mammal kills on these routes were estimated for a $50-\mathrm{km}$ stretch of highway and for a one-year basis, in order to make possible comparisons among these rates and the respective MDVs by ecoregion.

Estimates of the number of mammals run over on the two routes monitored systematically (BR 262 and BR 487) were performed by adjusting the total number of individuals found dead to a 50-km stretch and one-year basis. Results were tested for significance between these road stretches using the ChiSquare test.

\section{RESULTS}

\section{Species account}

A total of 472 roadkills were recorded on the roads of both ecoregions, 300 in the Cerrado and 172 in the Atlantic Forest. In most cases, roadkills were recorded on the two highways that were monitored systematically (see methodology), mainly in the western Cerrado (52\%) and in the extreme southeastern portion of the Atlantic ecoregion (24\%). Many other cases were widespread over both ecoregions.

The total number of mammal species surveyed in the entire region was 33, belonging to nine orders and 16 families. The most species-rich orders were Carnivora (14 species), Artiodactyla (6), Rodentia (4) and Cingulata (4). The smallest species was the guinea pig Cavia aperea Erxleben, 1777 (0.5 kg), and the largest was the tapir Tapirus terrestris (Linnaeus, 1758) $(240 \mathrm{~kg})$. Overall, many species were habitat generalist or adapted to savannas/open-habitats (Tab.I).

Ten of the 33 species recorded in these habitats were not found dead on the roads during the study period. Of the 10 species, four were ungulates - Blastocerus dichotomus (Illiger, 1815), Ozotoceros bezoarticus (Linnaeus, 1758), Pecari tajacu (Linnaeus, 1758), Tayassu pecari (Link, 1795) - and two were primates - Alouatta caraya (Humboldt, 1812) and Cebus libidinosus Spix, 1823 -; seven weighed more than $18 \mathrm{~kg}-$ Priodontes maximus (Kerr, 1792), Pteronura brasiliensis (Gmelin, 1788), Panthera onca (Linnaeus, 1758), B. dichotomus, O. bezoarticus, P. tajacu and T. pecari -, and four are threatened species $-P$. maximus, $P$. brasiliensis, $B$. dichotomus, and Dasyprocta azarae (Lichtenstein, 1823) - under the vulnerable and endangered categories according to the IUCN (2007) (Tab. I).

Overall, the species killed by vehicles in highest frequencies were Cerdocyon thous (Linnaeus, 1766) (34.5\%), Euphractus sexcinctus (Linnaeus, 1758) (23.6\%), Myrmecophaga tridactyla (Linnaeus, 1758) (11.5\%), Tamandua tetradactyla (Linnaeus, 1758) (7.7\%), and Dasypus novemcinctus (Linnaeus, 1758) (6.7\%). When ecoregions are considered, C. thous (31.7\%), E. sexcinctus (22.0\%), and $M$. tridactyla $(18.7 \%)$ were the species most frequently killed on the roads of the Cerrado, whereas C. thous (44.2\%), E. sexcinctus $(29.7 \%)$, and D. novemcinctus $(6.4 \%)$ were the most frequently species killed on the Atlantic Forest (Tab. I) roads. 
Table I. Relative (fraction from the total) and absolute (in parentheses) frequencies of mammals present in habitats and killed on roads in two adjacent ecoregions (Cerrado and Atlantic Forest) of south-western Brazil.

\begin{tabular}{|c|c|c|c|c|c|c|c|}
\hline \multirow{2}{*}{ Species / Sampling effort } & \multirow{2}{*}{ Order } & \multicolumn{3}{|c|}{ Habitat } & \multicolumn{3}{|c|}{ Roadkill } \\
\hline & & Cerrado & Atlantic & $p^{*}$ & Cerrado & Atlantic & $p^{*}$ \\
\hline & & 57 sites & 23 sites & & $2,700 \mathrm{~km}$ & $1,200 \mathrm{~km}$ & \\
\hline Didelphis spp. & Didelphimorphia & $0.00(0)$ & $0.01(2)$ & & $0.04(11)$ & $0.03(5)$ & $\mathrm{ns}$ \\
\hline Cabassous unicinctus ${ }^{* *}$ & Cingulata & $0.00(1)$ & $0.00(0)$ & & $0.00(1)$ & $0.00(0)$ & \\
\hline Dasypus novemcinctus & & $0.04(15)$ & $0.08(11)$ & 0.06 & $0.07(22)$ & $0.06(11)$ & ns \\
\hline Euphractus sexcinctus & & $0.05(19)$ & $0.04(5)$ & ns & $0.22(66)$ & $0.30(51)$ & 0.06 \\
\hline Priodontes maximus $\mathrm{b} * *$ & & $0.00(1)$ & $0.00(0)$ & & $0.00(0)$ & $0.00(0)$ & \\
\hline Myrmecophaga tridactyla a ${ }^{* *}$ & Pillosa & $0.05(18)$ & $0.01(2)$ & 0.03 & $0.19(56)$ & $0.01(1)$ & $<0.01$ \\
\hline Tamandua tetradactyla & & $0.02(8)$ & $0.01(1)$ & ns & $0.10(30)$ & $0.05(8)$ & 0.04 \\
\hline Cavia aperea & Rodentia & $0.01(4)$ & $0.04(5)$ & 0.06 & $0.00(1)$ & $0.02(3)$ & ns \\
\hline Cuniculus paca (Linnaeus, 1758) & & $0.02(9)$ & $0.02(3)$ & ns & $0.00(1)$ & $0.00(0)$ & \\
\hline Dasyprocta azarae ${ }^{\text {b }}$ & & $0.05(18)$ & $0.06(8)$ & ns & $0.00(0)$ & $0.00(0)$ & \\
\hline Hydrochoerus hydrochaeris & & $0.06(22)$ & $0.07(9)$ & ns & $0.01(3)$ & $0.05(9)$ & $<0.01$ \\
\hline Sylvilagus brasiliensis & Lagomorpha & $0.04(13)$ & $0.04(5)$ & ns & $0.00(1)$ & $0.01(1)$ & ns \\
\hline Alouatta caraya ${ }^{\star *}$ & Primates & $0.01(2)$ & $0.05(7)$ & $<0.01$ & $0.00(0)$ & $0.00(0)$ & \\
\hline Cebus libidinosus $s^{* *}$ & & $0.02(9)$ & $0.08(11)$ & $<0.01$ & $0.00(0)$ & $0.00(0)$ & \\
\hline Blastocerus dichotomus ${ }^{b}$ & Artiodactyla & $0.01(5)$ & $0.02(3)$ & ns & $0.00(0)$ & $0.00(0)$ & \\
\hline Mazama spp. & & $0.07(27)$ & $0.07(10)$ & ns & $0.01(2)$ & $0.01(1)$ & ns \\
\hline Ozotoceros bezoarticus a ** & & $0.01(4)$ & $0.00(0)$ & & $0.00(0)$ & $0.00(0)$ & \\
\hline Pecari tajacu & & $0.07(27)$ & $0.05(7)$ & ns & $0.00(0)$ & $0.00(0)$ & \\
\hline Tayassu pecari & & $0.02(8)$ & $0.00(0)$ & & $0.00(0)$ & $0.00(0)$ & \\
\hline Tapirus terrestris ${ }^{\mathrm{b}}$ & Perissodactyla & $0.09(34)$ & $0.07(10)$ & ns & $0.01(3)$ & $0.00(0)$ & \\
\hline Cerdocyon thous & Carnivora & $0.11(40)$ & $0.08(11)$ & 0.06 & $0.32(95)$ & $0.44(76)$ & $<0.01$ \\
\hline Chrysocyon brachyurus a ** & & $0.01(5)$ & $0.01(2)$ & ns & $0.01(4)$ & $0.00(0)$ & \\
\hline Lycalopex vetulus** & & $0.01(4)$ & $0.00(0)$ & & $0.00(0)$ & $0.01(1)$ & \\
\hline Leopardus pardalis & & $0.04(16)$ & $0.03(4)$ & ns & $0.00(1)$ & $0.00(0)$ & \\
\hline Panthera onca a & & $0.00(1)$ & $0.00(0)$ & & $0.00(0)$ & $0.00(0)$ & \\
\hline Puma concolor ${ }^{\text {a }}$ & & $0.03(12)$ & $0.05(7)$ & ns & $0.01(2)$ & $0.00(0)$ & \\
\hline Small cats ${ }^{a * *}$ & & $0.01(3)$ & $0.03(4)$ & ns & $0.01(4)$ & $0.01(1)$ & ns \\
\hline Eira barbara (Linnaeus, 1758) & & $0.00(0)$ & $0.00(0)$ & & $0.01(2)$ & $0.00(0)$ & \\
\hline Galictis cuja (Molina, 1782) & & $0.00(1)$ & $0.01(1)$ & ns & $0.00(1)$ & $0.01(1)$ & ns \\
\hline Lontra longicaudis (Olfers, 1818) & & $0.02(7)$ & $0.01(2)$ & ns & $0.00(0)$ & $0.01(1)$ & \\
\hline Pteronura brasiliensis ${ }^{\mathrm{c}}$ & & $0.01(2)$ & $0.00(0)$ & & $0.00(0)$ & $0.00(0)$ & \\
\hline Nasua nasua & & $0.02(6)$ & $0.01(1)$ & ns & $0.01(3)$ & $0.01(2)$ & ns \\
\hline Procyon cancrivorus & & $0.07(27)$ & $0.04(6)$ & ns & $0.03(9)$ & $0.03(6)$ & ns \\
\hline Total & & $1.00(368)$ & $1.00(137)$ & & $1.00(318)$ & $1.00(178)$ & \\
\hline Number of species & & 31 & 25 & & 21 & 16 & \\
\hline Number of threatened species & & 11 & 7 & & 5 & 2 & \\
\hline
\end{tabular}

1) Frequencies are shown by ecoregions, and significant differences between ecoregions' comparisons are circumscribed by rectangles showing the higher value $(p<0.05) .{ }^{*} p$-value comparing ecoregions by adjusting the sampling effort (binomial test); ns = nonsignificant values $(p>0.06)$.

2) IUCN (2007) threat categories (letter after species name): a: near-threatened; b: vulnerable; c: endangered. ** Savannic or open-habitat species.

3) "Small cats" referred mostly to Leopardus braccatus (Cope, 1889). 


\section{Effects by ecoregion}

\section{Habitats}

There was no overall difference between the two ecoregions in the relative frequencies (i.e., fractions from the total of records) of species in habitats (Wilcoxon test, $\mathrm{Z}=-0.19$, $\mathrm{p}=0.8486 ; \mathrm{n}=26$ species pairs). However, estimated abundances differed for some species when the two ecoregions were compared. This trend was significant for primates (A. caraya: binomial test, $\mathrm{Z}=3.45, \mathrm{p}=0.0006$; C. libidinosus: $\mathrm{Z}=3.00$, $\mathrm{p}=0.0027$ ), and marginally significant for the Brazilian guinea pig, C. aperea (binomial test, $\mathrm{Z}=1.89, \mathrm{p}=0.0593$ ) and the ninebanded armadillo, D. novemcinctus (binomial test, $\mathrm{Z}=1.86$, $p=0.0630)$ in the Atlantic ecoregion. Some species were also significantly more abundant in the Cerrado ecoregion, such as the giant anteater, $M$. tridactyla (binomial test, $\mathrm{Z}=-2.14$, $p=0.0324$ ), and other species with marginally significant frequencies such as the crab-eating fox, C. thous (binomial test, $\mathrm{Z}=-1.88, \mathrm{p}=0.0598)$, and the crab-eating raccoon, Procyon cancrivorus (G. Cuvier, 1798) (binomial test, $\mathrm{Z}=1.75, \mathrm{p}=0.0801$ ). We noted the absence of the giant anteater in the Atlantic ecoregion, and the occurrence of several species of mammals in similar frequencies in both ecoregions, including the largest mammal in the study region, the tapir Tapirus terrestris (Tab. I).

Several species and families were abundant in the Cerrado ecoregion (Fig. 2). As expected, these species are mainly savanna-dwellers such as myrmecophagids (anteaters), the yellow armadillo, E. sexcinctus, and the grassland fox, Lycalopex vetulus (Lund, 1842). Importantly, many ungulate species were abundant in this ecoregion, including the tapir, T. terrestris; peccaries, P. tajacu and T. pecari; and deer, Mazama spp.. Other abundant species in this ecoregion were the rabbit, Sylvilagus brasiliensis (Linnaeus, 1758), the ocelot, Leopardus pardalis (Linnaeus, 1758), and the crab-eating fox, C. thous, (Tab. I).

The NMDS analysis showed that axis 1 summarized the differences in estimated abundance among species and thus close similarities among them, placing Canidae (at left), and secondarily Cervidae, Dasypodidae and Tapiridae, as the most abundant, and Mustelidae and Agoutidae (at right) as the least abundant families. On the other hand, the analysis took into account differences in the ecoregions for axis 2, placing Myrmecophagidae (above) and Primates (below) in extreme positions in the diagram, corroborating findings of proportional abundance of anteaters and rarity of primates in the Cerrado ecoregion, and vice-versa for the Atlantic ecoregion. For instance, other families were important in Cerrado habitats such as Tayassuidae, Procyonidae and Mustelidae. By contrast, Dasypodidae and Caviidae were frequent in the Atlantic ecoregion (Fig. 2). The Shepard diagram significantly corroborated these results. Stress was low (0.0107) lending support to the analysis (Legendre \& Legendre 1998).

The number of threatened species found in habitats was higher in the Cerrado (11 species) in a magnitude of $57 \%$ more (Tab. I).

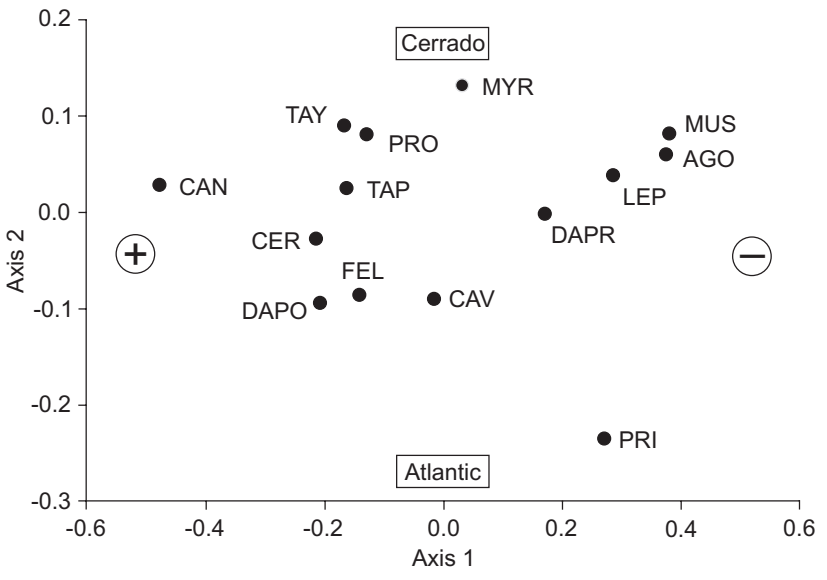

Figure 2. Diagram of NMDS analysis of frequency of occurrence in habitats for non-flying mammals between ecoregions of Cerrado and Atlantic Forest in south-western Brazil. Similarity distance was Euclidean. Stress value was 0.0107. Legends for families/order: (Ago) Agoutidae, (Can) Canidae, (Cav) Caviidae, (Cer) Cervidae, (Dapo) Dasypodidae, (Dapr) Dasyproctidae, (Fel) Felidae, (Lep) Leporidae, (Mus) Mustelidae, (Myr) Myrmecophagidae, (Tay) Tayassuidae, (Pri) Primates, (Pro) Procyonidae, (Tap) Tapiridae. Axis 1 is related to abundance records (e.g. higher ones at left, corresponding to signal +) and axis 2 to ecoregion affinities.

\section{Roadkills}

In general, there were no significant differences between relative frequencies of roadkills in both ecoregions (Cerrado and Atlantic Forest) (Wilcoxon text, $\mathrm{Z}=-0.18, \mathrm{p}=0.8590, \mathrm{n}=$ 11 species pairs). However, there were significant differences in frequencies of roadkills of some species, such as the giant anteater ( $M$. tridactyla: binomial test, $\mathrm{Z}=5.80, \mathrm{p}<0.0001$ ) and the collared anteater ( $T$. tetradactyla: binomial test, $\mathrm{Z}=2.06, \mathrm{p}$ $=0.0398$ ), respectively, which were commonly found dead on the highways of the Cerrado ecoregion, but seldom on those of the Atlantic ecoregion. The capybara, Hydrochoerus hydrochaeris (Linnaeus, 1758): binomial test, $\mathrm{Z}=-2.81, \mathrm{p}=$ 0.0049 ) was found dead on highways of the Atlantic ecoregion more often than on Cerrado roads. The same pattern of roadkill rate was observed for the crab-eating fox, C. thous: binomial test, $\mathrm{Z}=-2.72, \mathrm{p}=0.0065$ ) and for the yellow armadillo, $E$. sexcinctus: binomial test, $\mathrm{Z}=-1.85, \mathrm{p}=0.0639$ ) in the Atlantic ecoregion (Tab. I).

The incidence of roadkills was compatible with their estimated abundances in each ecoregion, with caviomorph rodents - e.g. H. hydrochaeris - being killed more often in the Atlantic ecoregion, and savannah species - e.g. myrmecophagids, and the maned wolf Chrysocyon brachyurus (Illiger, 1815) - being killed more often in the Cerrado ecoregion (Fig. 2). Generally abundant species suffered equivalent mortality in both ecoregions, but the rates were higher than expected for the crab-eating fox 
(C. thous) and the yellow-armadillo (E. sexcinctus) in the Atlantic ecoregion (particularly on BR 487). As expected from the observed frequencies in habitats, the giant anteater (M. tridactyla) was seldom killed by vehicles in the Atlantic ecoregion, but had a high rate of roadkills in the Cerrado ecoregion. By contrast, the tapir ( $T$. terrestris), a clearly frequent mammal in our data (slightly more frequent in the Cerrado than in the Atlantic forest), was seldom recorded killed on roads. On a smaller scale, the same pattern appeared for another ungulate species, the marshland deer B. dichotomus, which was not found dead on roads, although it had been recorded at a number of sites (Tab. I).

The mean daily volume (MDV) of vehicles on the highways monitored for killed mammals differed significantly between the two routes sampled, from the Cerrado and the Atlantic Forest ecoregions (Mann-Whitney test, $\mathrm{U}=916.0, \mathrm{p}<$ $0.0001, \mathrm{n}_{1}=58, \mathrm{n}_{2}=76$, respectively). MDV was higher in the Atlantic ecoregion $(2,733 \pm 336$ S.D. $)$ than in the Cerrado $(2,045$ \pm 634 S.D.).

Estimated numbers of individual mammals run over on the two routes monitored, per $50 \mathrm{~km}$ stretch and on an annual basis, revealed higher rates for BR 487 (114 individuals $/ 50 \mathrm{~km} /$ year) in the Atlantic ecoregion and lower for BR 262 (38 individuals $/ 50 \mathrm{~km} /$ year) in the Cerrado (Chi-square test, $\chi^{2}=37.0$, d.f. $=2, \mathrm{p}<0.0001)$

The number of threatened species found killed on roads was higher in the Cerrado (5 species) in a magnitude of $150 \%$ more than the Atlantic ecoregion (Tab. I).

\section{DISCUSSION}

In regard to frequencies of mammals in natural habitats and roads, some species typical of the savannas were most common in the Cerrado ecoregion, as expected from other regional (Santos-Filho \& Da Silva 2002, Rocha \& Dalponte 2006, Cáceres et al. 2007) and large-scale studies (FonseCA et al. 1996, EMmONs \& Feer 1997, Eisenberg \& Redford 1999). A main example of typical savannah species in the Cerrado ecoregion is the giant anteater $M$. tridactyla, besides some rare species such as the maned wolf $C$. brachyurus, and two armadillo species - Cabassous unicinctus (Linnaeus, 1758) and P. maximus. The giant-anteater was rarer in the Atlantic ecoregion, despite the occurrence of large portions of savanna inside this ecoregion (Fig. 1).

In contrast, caviomorph rodents such as capybaras, $H$. hydrochaeris, and guinea pigs, C. aperea, were found dead on roads more often in the Atlantic ecoregion. All cases of capybara roadkill occurred in locations where animals were crossing highways adjacent to bridges, specifically in sections contiguous to marshlands. The quite common occurrence of the marsh-deer, $B$. dichotomus, in the Atlantic ecoregion corroborates this, indicating that marshlands accompanying rivers are frequent in this ecoregion. We suppose that the Atlantic ecoregion, which is dominated by agriculture rather than cattle pasture (MATo Grosso do Sul 2008), favored the abundance of
Cavia, which is more adapted to grasslands (EISENBERG \& REDFord 1999) and is expected to be abundant in field crops. We noticed this association for primates as well: C. libidinosus is commonly found in crop fields (e.g. maize and soybeans) of the Atlantic ecoregion. On the other hand, the absence of $A$. caraya in the Cerrado ecoregion may be the result of a sampling artifact; this species is not expected to be found in disturbed habitats such as fragmented areas or near road situations, which prevailed in our field surveys. Even though our data suggest that primates are rare near roads of the Cerrado, we cannot infer from our results that primates occur in higher abundance in well-conserved places, far from roads, in this ecoregion.

The conservation status of the two ecoregions in southwestern Brazil was clearly different, with the Cerrado being generally better conserved than the Atlantic ecoregion (Mantovani \& Pereira 1998, Machado et al. 2004). This observation is clearly reflected in the differences of our results regarding species frequencies, species richness, and number of threatened species. In fact, the state of biological conservation of the Atlantic Forest is worse in the interior of Brazil; the largest forest remnants are located in the eastern coastal region of the country. Hence, from an original cover of $17.5 \%$, only $0.5 \%$ of the Atlantic Forest remains in the state of Mato Grosso do Sul (Conservation International do Brasil 2000).

In contrast with the Atlantic ecoregion, and despite the fact that the Cerrado is also a threatened physiognomy in southwestern Brazil, the Cerrado ecoregion in western Mato Grosso do Sul still includes large and well-conserved remnants (Mantovani \& Pereira 1998, Machado et al. 2004). The common occurrences of several mammal species and families in this ecoregion, for instance myrmecophagids, mustelids, peccarids and agoutids, point to a better state of regional conservation, and do not necessarily reflect original species distributions. If original species distribution patterns were the only factor in play here, the Atlantic forest domain would probably be richer in species (Fonseca et al. 1996, 1999). Therefore, our regional comparison between ecoregions revealed that the mammal community is more structured in the Cerrado ecoregion, with higher species and family richness, and more threatened species.

For the most part, our habitat records were confirmed by roadkills in both ecoregions, except for specific cases of accident avoidance by some agile or perhaps more intelligent species. For example, the naked-tailed armadillo C. unicinctus, the maned wolf $C$. brachyurus, and the coati $N$. nasua were rarely found in habitats or dead on roads.

The higher mean daily volume of vehicles (MDV) transiting in the southeastern part of the study region (mostly including the Atlantic ecoregion) easily explains why mammal families or species, in our data, were generally rarer in this region. In fact, the higher rates of mammals killed on BR 487 (more than $100 \mathrm{indiv} / 50 \mathrm{~km} /$ year) in the Atlantic ecoregion are likely a result of recent (2002) asphalt paving (see Melo \& SANTos-Filho 2007 for a similar result). With a lower MDV, the Cerrado 
ecoregion revealed a richer fauna in terms of both frequencies in natural habitats and roadkills, reflecting the good conservation status of this southwestern savanna formation (see CÁCERES et al. 2010). The number of threatened species is also an important record for this ecoregion, which shows that this ecoregion still safeguards a number of species regionally. On the other hand, human impact and deforestation (associated with road impact; see Santos \& Tabarell 2002) have been severe in eastern Mato Grosso do Sul, where the Atlantic ecoregion is located (MANTOVANI $\&$ Pereira 1998, Machado et al. 2004). These factors are thought to have caused increasing species rarity and local extinctions in this ecoregion. Our results for free-ranging species and for species killed on roads support this observation, with the Atlantic ecoregion showing more common and small body-sized species such as from Caviidae, Dasypodidae, and Felidae (Fig. 1), possibly reflecting the loss of larger sized mammals through local extinctions.

An interesting example of local extinctions is that of the tapir. This large species was recorded in both ecoregions, but somewhat more often in the Cerrado, with a few cases of roadkills overall. We empirically found that tapirs are difficult to spot in the southernmost portion of the Atlantic ecoregion where the species is only found in large and conserved forested areas, normally near large rivers. Our impression is that T. terrestris becomes more common in northern or western areas closer to the Cerrado ecoregion.

Based on the following empirical observations, we hypothesize that hunting for meat or for sport is more common in the Atlantic ecoregion than in the Cerrado. The latter harbors extensive farmlands that are well protected by farmers, which may decrease hunting substantially. By contrast, the Atlantic ecoregion contains smaller farm units and more urban areas (Mato Grosso do Sul 2008) which can be the source of more intensive hunting pressure (NCC, personal observation). Our impression is corroborated by the numerous reports of hunting of medium- and large-sized mammals in the eastern Atlantic Forest remnants (Chiarello 1999, Cullen-Jr et al. 2000. In these regions, species such as the tapir (T. terrestris), brocket deer (Mazama spp.), and white-lipped peccary (T. pecari) have significantly decreased population sizes, which corroborates our observations in the Atlantic ecoregion.

The two adjacent ecoregions studied revealed a similarity in mammal species composition and frequency of occurrence, with a significant number of savannic/generalist species occurring in both ecoregions. Even though the two adjacent ecoregions are expected to influence each another and share species (see KRASNOv \& SHENBrot 1998), our results have shown that there are limitations to this. Here we question whether the faunal similarity is the result of adaptive processes or whether it is a consequence of the higher disturbance levels in the Atlantic ecoregion. Disturbances may have contributed to a change in the mammal community over recent time (see Lomolino \& Perault 2004 as an example), although the marked presence of the giant-anteater in the Cerrado ecoregion and its rarity in the Atlantic ecoregion are supposed to be mainly adaptive.

In some cases, differences in occurrence and roadkill rates were detected in the Atlantic Forest-Cerrado ecotonal region, which is thought to be related to land use, such as farming (Atlantic Forest) or cattle ranching (Cerrado), and also to the form and intensity of human occupation in the region (high in the east, near São Paulo and Paraná states, which could be seen by MDV data for vehicles; and low in the western Cerrado, around the Pantanal biome).

\section{ACKNOWLEDGEMENTS}

We thank Fábio E.S. Costa (UEMS/FUNDECT) and Afrânio S. Soriano (UEMS/Dourados) for the incentive to study mammals in the state of Mato Grosso do Sul. The Ministério do Meio Ambiente (ProBio/Brazilian Government), the Universidade Federal do Mato Grosso do Sul (UFMS), FUNDECT (Mato Grosso do Sul), Fundação o Boticário de Proteção à Natureza, the Conservation International do Brasil/Pantanal, and the Universidade Federal de Santa Maria (UFSM) provided support for this study. We thank the volunteer students from UEMS and UFMS who assisted in the fieldwork and anonymous referees for the late review of the manuscript. Janet W. Reid assisted in revising the English text. N.C. Cáceres is a CNPq fellow.

\section{LITERATURE CITED}

Ayres, M.; M. Ayres Jr; D.L. Ayres \& A.S. Santos. 2003. Bioestat 3.0. Aplicações estatísticas nas áreas das Ciências Biológicas e Médicas. Belém, Sociedade Civil Mamirauá, 291p.

Borges, P.A.L. \& W.M. Tomás. 2004. Guia de rastros e outros vestígios de mamíferos do Pantanal. Corumbá, Embrapa Pantanal, 148p.

Cáceres, N.C.; M.R. Bornschein; W.H. Lopes \& A.R. Percequillo. 2007. Mammals of the Bodoquena Mountains, southwestern Brazil: an ecological and conservation analysis. Revista Brasileira de Zoologia 24: 426-435.

Cáceres, N.C.; J. Casella; C.F. Vargas; L.Z. Prates; A.A.M. Tombini; C.S.G Goulart; W.H. Lopes. 2008. Distribuição geográfica de pequenos mamíferos não voadores nas bacias dos rios Araguaia e Paraná, região centro-sul do Brasil. Iheringia, Série Zoologia, 98: 173-180.

Cáceres, N.C.; R.P. Napoli; J. Casella \& W. Hannibal. 2010. Mammals in a fragmented savannah landscape in southwestern Brazil. Journal of Natural History 44: 491-512.

Cherem, J.J.; M. Kammers, I.R. Ghizoni-Jr. \& A. Martins. 2007. Mamíferos de médio e grande porte atropelados em rodovias do Estado de Santa Catarina, sul do Brasil. Biotemas 20: $1-96$.

Chiarello, A.G. 1999. Effects of fragmentation of the Atlantic forest on mammal communities in south-eastern Brazil. Biological Conservation 89: 71-82. 
Clarke, G.P.; P.C.L. White \& S. Harris. 1998. Effects of roads on badger Meles meles populations in south-west England. Biological Conservation 86: 117-124.

Coelho, I.P.; A. Kindel \& A.V.P. Coelho. 2008. Roadkills of vertebrate species on two highways through the Atlantic Forest Biosphere Reserve, southern Brazil. European Journal Wildlife Research 54: 689-699.

Conservation International do Brasil. 2000. Avaliação e ações prioritárias para a conservação da Mata Atlântica e Campos Sulinos. Brasília, MMA/SBF, 40p.

Cullen-Jr, L.; R.E. Bodmer \& C.V. Padua. 2000. Effects of hunting in habitat fragments of the Atlantic forest, Brazil. Biological Conservation 95: 49-56.

DiAs, B.F.S. 1994. A conservação da natureza, p. 607-663. In: M.N. PINTo (Ed.). Cerrado: caracterização, ocupação e perspectivas. Brasília, Universidade de Brasília, 681p.

EISENberG, J.F. \& K.H. RedFord. 1999. Mammals of the Neotropics - the central Neotropics: Ecuador, Peru, Bolivia, Brazil. Chicago, University of Chicago Press, X+609p.

EMmons, L.H. \& F. FeER. 1997. Neotropical rainforest mammals: a field guide. Chicago, University of Chicago Press, $\mathrm{XVI}+307 \mathrm{p}$.

Fonseca, G.A.B.; G. Herrmann; Y.R.L. Leite; R.A. Mittermeier; A.B. Rylands \& J.L. PatTon. 1996. Lista anotada dos mamíferos do Brasil. Occasional Papers in Conservation Biology 4: 1-38.

FonseCA, G.A.B.; G. HeRrMANn \& Y.R.L. Leite. 1999. Macrogeography of Brazilian mammals, p. 549-563. In: J.F. EISENBERG \& K.H. REDFORD (Eds). Mammals of the Neotropics - the Central Neotropics: Ecuador, Peru, Bolivia, Brazil. Chicago, University of Chicago Press, X+609.

Forman, R.T.T. \& L.E. Alexander. 1998. Roads and their major ecological effects. Annual Review of Ecology and Systematic 29: 207-231.

Forman, R.T.T.; D. Sperling; J.A. Bissonette; A.P. Clevenger; C.D. Cutshall; V.H. Dale; L. Fahrig; R. France; C.R. Goldman; K. Heanue; J.A. Jones; F.J. Swanson; T. Turrentine \& T.C. Winter. 2003 Road ecology: science and solutions. Washington, Island Press, $481 \mathrm{p}$.

HAMmER, Ø.; D.A.T. HARPER \& P.D. RyAn. 2001. PAST: Paleontological Statistics Software Package for Education and Data Analysis. Paleontologia Electronica 4: 1-9.

Hirota, M.M. 2005. Monitoramento da cobertura da Mata Atlântica brasileira, p. 60-65. In: C. Galindo-Leal \& I.G. CÂmara (Eds.). Mata Atlântica: biodiversidade, ameaças e perspectivas. Belo Horizonte, Fundação SOS Mata Atlântica, Conservação Internacional, 472p.

IUCN, 2007. 2007 IUCN Red List of Threatened Species. Available online at: http://www.iucnredlist.org. [Accessed: 3.V2008].

Kark, S.; T.F. Allnutt; N. Levin; L.L. Manne \& P.H. Williams. 2006. The role of transitional areas as avian biodiversity centres. Global Ecology and Biogeography 16 (2): 187-196. doi: 10.1111/j.1466-8238.2006.00274.x
Krasnov, B.R. \& G.I. Shenbrot. 1998. Structure of communities of ground-dwelling animals at the junction of two phytogeographic zones. Journal of Biogeography 25: 11151131.

Legendre, P. \& L. Legendre. 1998. Numerical ecology. Amsterdam, Elsevier, XV+853p.

Lomolino, M.V. \& D.L. Perault. 2004. Geographic gradients of deforestation and mammalian communities in a fragmented, temperate rain forest landscape. Global Ecology and Biogeography 13: 55-64.

López-GonZÁlez, C. 2004. Ecological zoogeography of the bats of Paraguay. Journal of Biogeography 31: 33-45.

Machado, R.B.; M.B. Ramos Neto; P.G.P. Pereira; E.F. Caldas; D.A. Gonçalves; N.S. Santos; K. Tabor \& M. Steininger. 2004. Estimativas de perda da área do Cerrado brasileiro. Brasília, Unpublished Report, Conservação Internacional, 26p.

Mantovani, J.E. \& A. Pereira. 1998. Estimativa de integridade da cobertura vegetal de Cerrado através de dados TMLandsat, p. 1455-1466. In: Anais do IX Simpósio Brasileiro de Sensoriamento Remoto, Santos, Brasil. Available in World Wide Web at: http://marte.dpi.inpe.br [Accessed on 20.V.2008].

Mato Grosso do Sul. 2008. Governo do Estado do Mato Grosso do Sul. Available online at: http://www.ms.gov.br [Accessed: 18.V.2008].

Melo, E.S. \& M. Santos-Filho. 2007. Efeitos da BR-070 na Província Serrana de Cáceres, Mato Grosso, sobre a comunidade de vertebrados silvestres. Revista Brasileira de Zoociências 9: 185-192.

OrLowsky, G. \& L. NowAK. 2006. Factors influencing mammal roadkills in the agricultural landscape of south-western Poland. Polish Journal of Ecology 54: 283-294.

Rocha, E.C. \& J.C. Dalponte. 2006. Composição e caracterização da fauna de mamíferos de médio e grande porte em uma pequena reserva de Cerrado em Mato Grosso, Brasil. Revista Árvore 30 (4): 669-678.

Santos, A.M. \& M. Tabarelli. 2002. Distance from roads and cities as a predictor of habitat loss and fragmentation in the Caatinga vegetation of Brazil. Revista Brasileira de Biologia 62: 897-905.

Santos-Filho, M. \& M.N.F. Da Silva. 2002. Uso de hábitats por mamíferos em área de Cerrado do Brasil central: um estudo com armadilhas fotográficas. Revista Brasileira de Zoociências 4: 57-73.

Woods, J.G. \& R.H. Munro. 1996. Roads, rails and the environment: wildlife at the intersection in Canada's western mountains. Orlando, Transportation related wildlife mortality seminar. Available in World Wide Web at: http://www.icoet.net [Accessed on 25.I.2009].

Submitted: 26.II.2009; Accepted: 28.I.2010.

Editorial responsibility: Heraldo L. de Vasconcelos 